\title{
In vivo studies of substances used in the cosmetic industry
}

\author{
Joanna Igielska-Kalwat, Joanna Gościańska, Beata Witkowska, Izabela Nowak
}

Faculty of Chemistry, Laboratory of Applied Chemistry, Adam Mickiewicz University, Poznan, Poland

Adv Dermatol Allergol 2016; XXXIII (3): 163-169

DOI: $10.5114 / a d a .2016 .60607$

\begin{abstract}
Cosmetic producers are obliged to guarantee the safety and stability of their products. The current legal regulations are based on the European Union Directive (1223/2009) of 30 November 2009. The main aim of the directive is to formulate criteria of safety of a cosmetic product and requirements that it must meet to be placed on the market. A new cosmetic product is subjected to thorough investigation prior to its introduction on the market. It should be studied not only with respect to its safety, but also with respect to its effectiveness declared by the producer. The studies are performed in vivo, by the contact or epidermal patch tests on the human skin.
\end{abstract}

Key words: in vivo study, sensorial evaluation, patch tests.

\section{Introduction}

On the basis of the EU Directive of 30 November 2009, the Polish Act on cosmetic products of 30 March 2001 (Journal of Laws of 2001, item 42, as amended) was enacted; the Act in its consolidated text is contained in the Journal of Laws of 2013, item 475. The above Acts makes the producer fully responsible for the product [1]. The regulations describe the conditions and requirements for placing a new product on the market.

The documentation of the product should include [2] specification of the qualitative and quantitative composition of the product, physical/chemical and microbiological properties, purity of components, final physicochemical evaluation including the product stability on storing, microbiological evaluation of the final product, criteria of chemical and microbiological purity of the final product, description of the method of production (compliant with good manufacturing practice), documents confirming the activity declared on the packing, information on undesirable side effects on human health, evaluation of the effect of the product on human health, toxicological characterisation, chemical structure, degree of contact with human body established by the application-apparatus methods $[1,3]$.
The application-apparatus studies performed on a group of volunteers by the in vivo method are the subject of this paper. A new cosmetic product is thoroughly characterised prior to introduction on the market. The safety of its use and the effectiveness of its activity declared by the producer are tested. The tests are performed in vivo by the so called patch tests on human skin [4]. Only the substances and products attested as nontoxic and non-caustic can be tested on humans [5, 6].

The in vivo studies are performed on healthy volunteers selected taking into account sex, age and type of skin and possible skin problems. The participants are divided into two groups, one is given a cosmetic product with an active substance studied and the other is the control group whose members are given the cosmetic product without the active substance (placebo). Prior to each test the subjects are dermatologically examined. Their type and state of skin are determined, the information on substances they show allergic response to and other information is collected, e.g. on the past or present skin diseases and the treatment applied and on the general state of health. Each volunteer is asked to sign formal consent to participate in the tests and the person conducting the study is obliged to give details of the study and possible side effects. Each person taking

Address for correspondence: Joanna Igielska-Kalwat, Faculty of Chemistry, Laboratory of Applied Chemistry, Adam Mickiewicz University, 89b Umultowska St, 61-614 Poznan, Poland, phone: +48 501667 270, e-mail: ji11602@amu.edu.pl Received: 14.08.2014, accepted: 20.10.2014. 
part in the test is given a formal written instruction of the cosmetic use and the questionnaire to be filled when using it. The information from the questionnaire is used for possible further improvement of a given product. Depending on the type of product and expected effects, the test can last from a few to more than 10 weeks. The subjects apply the product tested on the forearm twice a day, in the morning and in the evening. During the test they are not allowed to use any other cosmetic products than the one tested [7, 8].

Dermatological evaluation of the effect of a given active substance or product is performed on the basis of one-time occlusive tests, repeated occlusive tests and repeated open application tests. The methods have been developed for sodium laureth sulphate (SLES) as a model irritating substance $[9,10]$. The patch tests are mainly used to check the type of response to a given cosmetic product (allergic or irritating).

A series of standard tests can also indicate a component responsible for the irritation [11]. One-time application in the patch test for 24 or $48 \mathrm{~h}$ is very simple. It permits identification of substances that can produce acute response and irritation. The one-time application is used to evaluate the irritating potential of a given cosmetic. The method does not correspond to the real exposure to the irritating agent in everyday life as it is usually long-lasting and repeatable [12-14]. Many authors have been concerned with the repeated occlusive patch tests. Frosch and Kligmanin proposed a 5-day pattern: to apply a given substance for $24 \mathrm{~h}$ on the first day and then for 6 hours on subsequent 4 days [15-17].

Many models have been proposed for better representation of the use of cosmetic products in everyday life, for instance application of a given substance on the skin in occlusive chamber twice a day for 45 min for 5 days or twice a day for 45 min for 3 weeks [17] or once a day for $2 \mathrm{~h}$ over the period of 3 weeks $[18,19]$.

Since the 1990s, evaluation of the irritating effect of active substance has been performed on the basis of a short-time exposure of skin to a given substance in the patch test. The reaction of the skin is compared to that caused by the simultaneous application of the standard irritating substance SLS in a 20\% wt. water solution [20]. The test patches are applied on the skin of the arms. The time of exposure gradually increases from $30 \mathrm{~min}$, to 1 , 2, 3 and up to $4 \mathrm{~h}$. The skin reaction is evaluated at 24, 48 and $72 \mathrm{~h}$ after the exposure and is described on the scale from 0 to $3+$. The tests take 7 weeks for the substance application once a week or 2-3 weeks when the substance is applied twice a week. If a positive response to a given active substance is observed at the same or higher frequency than the response to SLES, then the substance is considered as an irritant [21, 22]. According to Basketter et al. [6], the method is the basis for classi- fication of the active substances of cosmetic products as irritants or non-irritants of human skin [23].

In general, there are three main methods of evaluation based on the use of patch tests [24]:

- one-time occlusive test (Schwartz-Peck test);

- repeated occlusive test (Human Repeated InsultPatch Test - HRIPT):

- with broken exposure (Draize test, Shelanski - Shelanski test and Voss-Griffith test),

- with continuous exposure (modified Draize test),

- human Maximization Test.

In the Schwartz-Peck test [25], patches covered with the active substance in different doses are applied to the subject skin. Results are checked at 24, 72 and $94 \mathrm{~h}$ after application and then after 10 or 14 days. After removal of the patch test, the skin is carefully examined. In the Full Schwartz-Peck test [25] the patches are still used for 4 weeks after the preliminary test. This repeated examination is aimed at detection of strong or dormant allergic reactions [26]. In the Draize test, a series of 10 patch tests are applied on the skin of the arm or back for $24 \mathrm{~h}$, every second day and 3 times a week. After each application, the skin is examined for the presence of swelling and erythema. Two weeks after the last test, the so-called challenge patch is applied for $24 \mathrm{~h}$ and then the skin is examined. The results of examination are compared with the earlier results [27].

The Shelanski-Shelanski test [28] is similar to the Draize test but the difference is that a series of 15 patch tests is applied on the same site of the skin. If erythema or swelling appears, the next patch test should be applied on the neighbouring part of skin. After 2-3 weeks from the last patch test application, the challenge patch is applied for $48 \mathrm{~h}$. The results of the final test are compared with the earlier ones [28].

The Voss-Griffith test is similar to that of Draize, but the difference is that a series of 9 patch tests is applied for $24 \mathrm{~h}$ over the period of 3 weeks. The challenge patch is applied after 2 weeks from the last test and it is applied at two sites of the skin simultaneously. The first is applied on the arm skin tested earlier and the second on the other arm. This analysis permits simultaneous tests of four materials. If the results are unclear, the repeat application of challenge patch is recommended [29].

The modified Draize test differs from the original Draize test by the fact that the patch tests are changed three times a week until 10 tests are used. The patch test is applied on the same site, unless skin irritation is observed, then the next test is applied on the neighbouring skin area. The challenge patch is applied for $72 \mathrm{~h}$ in 2 weeks after the completion of the series of main tests [30]. The human maximization test comprises a series of 5 patch tests applied for $48 \mathrm{~h}$ with a 24-hour break. Prior to the main test, for $24 \mathrm{~h}$ the preliminary test with 5\% wt sodium laureth sulphate is applied before introduction of the potentially irritating substance in a concentration 
Table 1. Contact tests [32]

\begin{tabular}{|c|c|c|c|c|c|}
\hline Test & Site of exposure & $\begin{array}{c}\text { Number } \\
\text { of exposures }\end{array}$ & $\begin{array}{c}\text { Duration } \\
\text { of exposure [h] }\end{array}$ & Challenge exposure & $\begin{array}{c}\text { Number of } \\
\text { subjects tested }\end{array}$ \\
\hline Schwartz-Peck & Upper arm & 1 & $24-72-96$ & $\begin{array}{l}48 \text { h patch test } \\
+4 \text {-week use testin } \\
\text { a complete test }\end{array}$ & 200 \\
\hline Draize & $\begin{array}{l}\text { Upper arm or } \\
\text { upper back }\end{array}$ & 10 & 24 & $24 \mathrm{~h}$ patch test & 200 \\
\hline Shelanski-Shelanski & Upper arm & 15 & 24 & $48 \mathrm{~h}$ patch test & 200 \\
\hline Voss-Griffith & Upper arm & 9 & 24 & $24 \mathrm{~h}$ patch test & 200 \\
\hline Modified Draize & Upper or lower back & 10 & 48 & $72 \mathrm{~h}$ patch test & 200 \\
\hline Human maximization & $\begin{array}{l}\text { Application of SLS on } \\
\text { forearm or calf }\end{array}$ & 5 & 48 & $\begin{array}{c}5 \% \text { wt of SLES for } 24 \mathrm{~h} \text {, then } \\
48 \mathrm{~h} \text { patch test with the } \\
\text { substance studied }\end{array}$ & 25 \\
\hline
\end{tabular}

that would produce moderate erythema. In 2 weeks after the last test, the degree of irritation is estimated on the basis of a 48-hour patch test with the maximum nonirritating concentration of the active substance placed on the slightly irritated skin. Results are evaluated after 24 and $48 \mathrm{~h}$ [31] (Table 1).

Thin-layer Rapid Use Epicutaneous test or TRUE test is a ready-made patch test applied usually on the skin of the back or forearm (Figure $1 \mathrm{~A}$ ). The patch comprises 24 windows, of which 23 contain the substances studied and the last window is the control one (Figure $1 \mathrm{~B}$ ). The allergens are contained in hydrophilic gel coated with the watertight polyester.

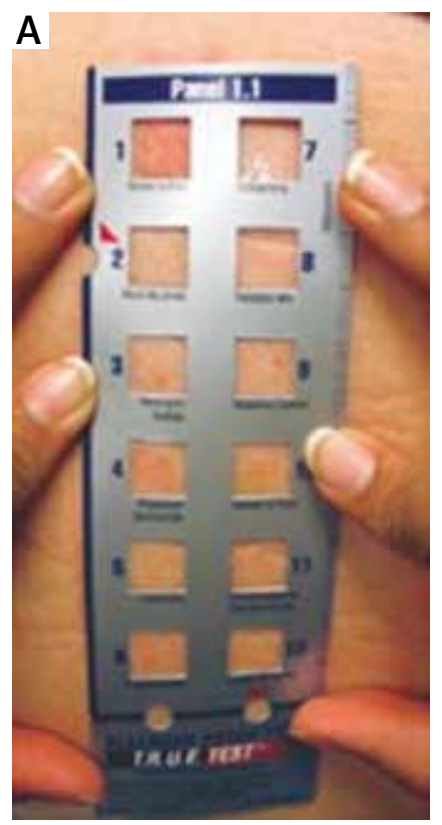

The content of allergens is selected according to the European directive that defines $75 \%$ of reasons for the allergic contact skin inflammation. This test permits identification of the subject's allergic responses to any of the 47 allergic substances. Up to date, it is the only patch test approved by the Food and Drug Administration (FDA) and EU legal regulations that apply to therapeutic substances [33-35].

Repeated Open Application Test or ROAT involves a short-time exposure of skin to the substance studied without occlusion, at a certain frequency [38]. ROAT as well as the provocative use test (PUT) are the so-called use tests proposed to more accurately correspond to everyday use of a given product.

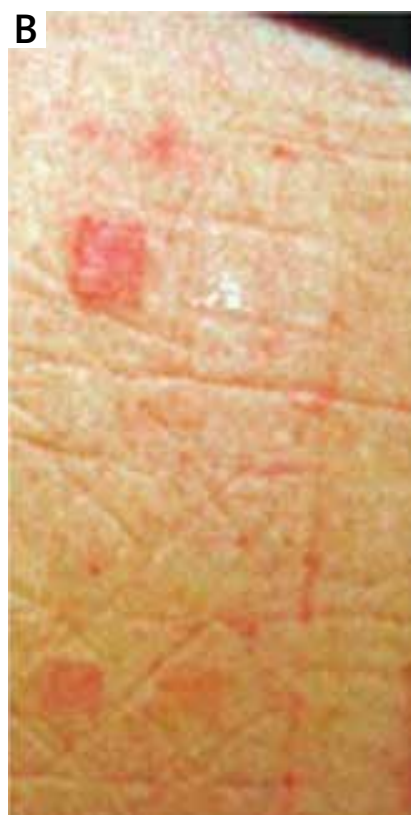

Figure 1. TRUE test applied on the skin of the back (A) and the response of the skin after 48-hour exposure to Ni and Co (B) $[36,37]$ 
In these tests a certain amount of the substance studied is applied once or twice a day on the skin of the forearm, elbow pit or other site for a period of from 4 to 28 days [9, 39-41]. The drawback of the tests is their duration. A variation of the test is the wash test and exaggerated wash test in which a certain area of the skin (usually forearm or arm) is washed with the substance studied at a certain frequency and for a certain period of time [42]. The procedures involve the induction of skin irritation by washing the skin with the active substance studied 3 times a day for 6 days, and then maintaining the irritation by twice a day exposure. The substance studied is applied in different concentrations producing skin irritation [43].

The clinical examination of biophysical properties is made and the results are expressed on a special scale. No perfect agreement has been found between the evaluation of the irritating effect of a given substance on the basis of occlusive tests and open tests. The patch tests are used to evaluate the acute irritating effect, while the use tests permit evaluation of the ability of a given substance to produce irritation as a result of repeated exposure [44-46].

Direct Peptide Reactivity Assay DPRA of glutathione (GSH) and two other promising in vitro methods developed for evaluation of allergic response of the skin: human cell line activation (hCLAT) and the myeloid u937 skin sensitisation test (MUSST) have been optimised and admitted by the European Centre for the Validation of Alternative Methods (ECVAM) in 2009 for preliminary validation [47]. Until 30 June 2014, only DPRA [48] was validated.
The allergic skin response is also predicted on the basis of the chemical structure and properties of related substances by the Structure-Activity Relationship (SAR) and Quantitative Structure-Activity Relationship (QSAR) methods based on in silico methodology [49]. Table 2 presents the methods currently used for evaluation of the allergic response or irritation, including the occlusive and open patch tests.

After the tests the skin is subjected to clinical examination, also known as instrumental evaluation. The presence of erythema, exfoliation, clefts is checked and some biophysical parameters are measured (by non-invasive methods) including: level of moisture content, content of grease on the skin surface and transepidermal water loss.

The moisture content depends on the moisture of the corneal layer of epidermis and its measurement is based on electric properties of skin by a corneometer. The content of grease on the skin is based on the photometry of grease spot [50] by a submeter. This instrument measures the content of grease on the skin with the help of plastic foil whose light transparency depends on the content of grease on its surface. This measurement brings information on the functioning of the skin sebaceous glands.

The skin elasticity is measured by a probe which has a special opening through which skin is sucked in under reduced pressure. The amount of skin sucked in is greater if the skin is flabby than if the skin is firm. The results are expressed in the form of a dimensionless coefficient of skin elasticity (R). The surface of the skin is covered with furrows [51] and other irregularities. The state of the skin

Table 2. Currently used methods for evaluation of an active substance on human skin [49]

\begin{tabular}{|c|c|c|c|c|c|c|c|}
\hline Method & 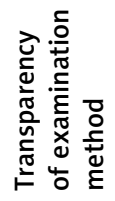 & 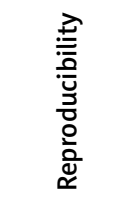 & 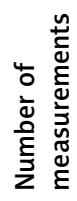 & 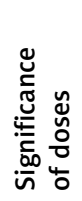 & $\frac{. \frac{5}{}}{\frac{.}{0}}$ & 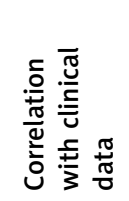 & 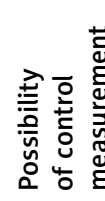 \\
\hline \multicolumn{8}{|l|}{ In vivo: } \\
\hline Single application patch tests & +++ & +++ & + & +++ & +++ & - & + \\
\hline HRIPT (Human Repeated Insult Patch Test) & + & Unknown & ++ & +++ & Unknown & - & - \\
\hline ROAT (load tests) & +++ & +++ & +++ & +++ & +++ & - & +++ \\
\hline \multicolumn{8}{|l|}{ In silico: } \\
\hline SAR & + & +++ & - & - & - & Unknown & - \\
\hline QSAR & +++ & +++ & - & - & - & Unknown & - \\
\hline \multicolumn{8}{|l|}{ In chemico: } \\
\hline GSH & +++ & +++ & +++ & +++ & - & ++ & - \\
\hline DPRA & +++ & +++ & - & +++ & - & ++ & - \\
\hline \multicolumn{8}{|l|}{ In vitro: } \\
\hline h-CLAT & +++ & +++ & +++ & +++ & - & ++ & +++ \\
\hline MUSST & +++ & +++ & +++ & +++ & - & ++ & +++ \\
\hline
\end{tabular}

+++ good, ++ rather good, + poor. 
surface, depending on internal and external factors, is described by the skin smoothness. This parameter describing the skin is evaluated on the basis of images in UV radiation. Using a special camera, microtopographic photographs of the surface of epidermis are taken, revealing all wrinkles, furrows and irregularities. The method of UV imaging permits evaluation of the roughness and smoothness of epidermis, degree of epidermis exfoliation, length, width and depth of wrinkles, a general condition of the skin. The colour of the skin is evaluated according to the colorimetric scale [52].

Measurement is made by a probe permitting evaluation of the intensity of skin coloration. The last but also the most important parameter describing the skin state is the transepidermal water loss by a tewameter or evaporimeter which measure the rate of water evaporation from the skin surface. The measurement gives information on the duration of correct skin moisture. The degree of erythema and intensity of coloration of pigment spots are also evaluated [53].

Moreover, the state of skin is described on the basis of sensory examination. Sensory analysis is a scientific discipline concerned with measurement and evaluation of a product with the help of human senses (sight, smell, taste, touch and hearing). The evaluation is usually performed by a trained panel of human assessors on whom the product is tested in specified and controlled conditions [54].

The experiments can be performed by the half by half method. The member of the panel gets two test packages of preparations containing the cosmetic products studied of different composition or different concentration of the active component. There is also the double blank method in which neither the person conducting the experiment nor the person testing the product know what the difference between the preparations is. Sensory analysis of cosmetic products are fundamental for their full evaluation. On the basis of the consumer testing it is possible to elicit the information on the features of the products most important for certain groups of consumers and their preferences. The subjective opinions of consumers are recorded and then analysed by the uniform verification standards. The results are used by producers in the process of introduction and improvement of their products [55-57].

\section{Conclusions}

Cosmetic industry is working on new alternative methods for evaluation of the active substances in the cosmetic products on the basis of determination of their effectiveness, toxicity, tendency to evoke allergic reaction and skin irritation. Tests on volunteers are a very important part of the process of product evaluation providing information on the product activity and consumer satisfaction with it. The test on people have to conform with the World Medical Association Declaration of Helsinki [58], EU Directive 2001/20/EC of 4 April 2001 [59], Directive of the Ministry of Health of 2 May 2012 on good clinical practice [60], and the Directive of the Ministry of Health of 22 May 2013 on good laboratory practice [61].

\section{Conflict of interest}

The authors declare no conflict of interest.

\section{References}

1. Ustawa z dnia 30 marca 2001 r. o kosmetykach Dz.U. 2001.42.473 wraz z późniejszymi zmianami (tekst pierwotny: Dz. U. 2001 r. Nr 42 poz. 473) (tekst jednolity: Dz. U. 2013 r. poz. 475).

2. Rozporządzenie Parlamentu Europejskiego i Rady (WE) nr 1223/2009 z dnia 30 listopada 2009 r. dotyczące produktów kosmetycznych. Dz.U.L, 342 z 22.12.2009, 59-209.

3. Gościańska J, Olejnik A, Nowak I. Analityka kosmetyczna. Cursiva. Kostrzyn, Polska 2012.

4. Dębowska R. In vitro and ex vivo tests in contemporary cosmetology. Chemik 2010; 2: 74-9.

5. Chomiczewska D, Kieć-Świerczyńska M, Kręcisz B. Kontaktowe zapalenie skóry z podrażnienia. Część II. Metody badania działania drażniącego substancji aktywnych. Med Pracy 2009; 3: 209-14.

6. Basketter DA, Whittle E, Griffiths A, York M. The identification and classification of skin irritation hazard by a human patch test. Food Chem Toxicol 1994; 32: 769-73.

7. Kvang HL. Tissue-engineered human living skin substitutes: development and clinical application. Yonsei Med J 2000: 41: 774-9.

8. Klausner M, Ayehunie S, Hayden PJ, et al. Full thickness EpiDerm, a dermal-epidermal skin model to study epithelial-mesenchymal interaction. J Invest Dermatol 2002; 119: 260-6.

9. Kubilus J, Haycken PJ, Ayehunie S, et al. Full thickress EpiDerm: a dermal-epidermal skin model to study epithelial mesenchymal interactions. Alter Lab Anim 2004; 1A: 75-82.

10. Tupker RA, Willis C, Berardesca E, et al. Guidelines on sodium lauryl sulphate (SLS) exposure tests. A report from the Standarization Group of the European Society of Contact Dermatitis. Contact Dermatitis 1997; 37: 53-69.

11. Spiewak R. Patch testing for contact allergy and allergic contact dermatitis. Open Allergy J 2008; 1: 42-51.

12. Dickiel H, John SM. Ratio of irritant contant dermatitis to allergic contact dermatitis in occupation skin disease. J Am Acad Dermatol 2003; 2: 360-1.

13. Fluhr JW, Daelenski R, Angelova-Fischer I, et al. Skin irritation and sensitization: mechanisms and new approaches for risk assessment. Skin Pharmacol Physiol 2008; 21: 191-202.

14. Belsito DV. Occupational contact dermatitis. Etiology, prevalence, and resultant impairment/disability. J Am Acad Dermatol 2005; 53: 303-13.

15. Levin CY. Maibach HI. Irritant contact dermatitis is there an immunologic component? Int I Immunopharmacol 2002; 2: 183-9.

16. Mutschler E, Geisslinger G, Kroemer HK, et al. Kompendium farmakologii i toksykologii Mutschlera. Med. Pharm, Wrocław, Poland 2008

17. Berardesca E, Distante F. The modulation of skin irritation. Contact Dermatitis 1994; 31: 281-7. 
18. Berardesa E, Barbareschi M, Veraldi S, Pimpinella V. Evaluation of efficacy of a skin lipid mixture in patients with irritant contact dermatitis, allergic contact dermatitis or atopic dermatitis: a multicenter study. Contact Dermatitis 2001; 445: 280-5.

19. Kartono F, Maibach HI. Irritants in combination with a synergistic or additive effect on the skin response an overview of tandem irritation studies. Contact Dermatitis 2006; 54 303-12.

20. Sertol A, Gola M, Martinelli C, et al. Epidemiology of contact dermatitis. Semin Dermatol 1989; 8: 120-6.

21. Robinson MK, Kruszewski EK, Al-Atrash I, et al. Comparative assessment of the acute skin irritation potential of detergent formulations $\mathrm{R}$ using a novel human 4-h patch test method. Food Chem Toxicol 2005; 43: 1703-12.

22. Tupker RA, Pinnagoda J, Nater JP. The transient and cumulative effect of sodium lauryl sulphate on the epidermal barrier assessed by transepidermal water loss: inter-individual variation. Acta Derm Venereol 1990; 70: 1-5.

23. Chomiczewska D, Kieć-Swierczyńska M, Kręcisz B. Kontaktowe zapalenie skóry z podrażnienia Część II. Metody badania działania drażniącego substancji chemicznej. Medycyna Pracy 2009; 60: 209-14.

24. Albert M, Kligman MD. The identification of contacts allergents by human assay. J Invest Dermatol 1966; 47: 367-74.

25. Draize JH. Dermal toxicity. Appraisal of the safety of chemicals in foods, drugs and cosmetics. Association of food and drug officials of the United States, Texas State Department of Health, Austin, Texas 1959.

26. Hannuksela A, Hannuksela M. Irritant effects of a detergent in wash, chamber and repeated open application tests. Contact Dermatitis 1996; 34: 134-7.

27. Podlewska K. Testy kontaktowe - ich rola w badaniu kosmetyków. Świat Przemysłu Kosmetycznego 2011; 2: 12-3.

28. Jirova D, Liebsch M, Basketter D, Spiller E. Comparison of human skin irritation and photo-irritation patch test data with cellular in vitro assays and animal in vivo data. AATEX 2008; 14: 359-65.

29. Basketter D. The human repeated insult patch test in the 21st centure: a commentary. Cutan Ocul Toxicol 2009; 28: 49-53.

30. Romano A, Marinella V, Gaeta F, et al. Patch testing in nonimmediate drug eruptions. Allergy Asthma Clin Immuno 2008; 2: 66-74.

31. Barany E, Lindberg M, Loden M. Biophysical characterization of skin damage and recovery after exposure to different surfactants. Contact Dermatitis 1999; 40: 98-103.

32. Rycroft RJG, Menne T, Frisch PJ, Lepooittevin JP. Textbook of contact dermatitis. Springer, Berlin 2001.

33. Fischer T, Kreilgård B, Maibach, HI. The true value of the TRUE test for allergic contact dermatitis. Curr Allergy Asthma Rep 2001; 1: 316-22.

34. Gollhausen R, Przybila B, Ring J. Reproducibility of patch test results: comparison of TRUE Test and Finn Chamber test results. J Am Acad Dermatol 1989; 2: 843-6.

35. Kajds TM, Gartstein V. Review of the instrumental assess ment of skin: efects of cleasing products. J Soc Cosmet Chem 1991; 42: 249-71.

36. Kosboth M, Chin-Loy A, Lyons R, et al. Malar rash caused by metal allergy in a patient with systemic lupus erythematosus. Nat Clin Pract Rheumatol 2007; 3: 240-5.

37. http://alergiaweb.es; Available at: 14.07.2014.
38. Basketter DA, Chamberlain M, Griffiths HA, et al. The classification of skin irritants by human patch test. Food Chem Toxicol 1997; 35: 845-52.

39. Spoo J, Wigger-Alberti W, Berbadt U, et al. Skin cleansers: three test protocols for the assessment of iritancy ranking. Acta Derm Venereol 2002; 82: 13-7.

40. Zaghi D, Maibach HO. Quantitative relationship between patch test reactivity and use test reactivity: an overview. Cutan Ocul Toxicol 2008; 27: 241-8.

41. Nigam PK. Adverse reactions to cosmetics and methods of testing. Indian J Dermatol Venereol Leprol 2009; 75: 10-9.

42. Spiewak R. Alergia kontaktowa - diagnostyka i postępowanie. Alerg Astma Immun 2007; 12: 109-27.

43. Tupker RA, Schuur J, Coenraads PJ. Irritancy of antiseptics tested by repeated open exposures on the human skin, evaluated by non-invasive methods. Contact Dermatitis 1997; 5: 213-7.

44. Slotosch CM, Kampt G, Loffler H. Effects of skin disinfectants and detergents on skin irritation. Contact Dermatitis 2007; 57: $235-41$.

45. Clemmensen A, Andersen E, Petersen TK, et al. The irritant potential of n-propanol (nonanoic acid vehicle in cumulative skin irritation: a validation study of two different human in vivo test model. Skin Res Technol 2008; 14: 277-86.

46. Rogiers V, Balls M, Basketter D, Berrardesco E. The potential use of non-invasive methods in the safety assessment of cosmetic products. Atla 1999; 27: 616-37.

47. Sprawozdanie na temat opracowywania, uznawania i prawnego przyjmowania metod alternatywnych wobec testów na zwierzętach w branży produktów kosmetycznych (2008) http: eur-lex.europa.eu. Available at: 14.07.2014.

48. http://ihcp.jrc.ec.europa.eu/our labs/eurl-ecvam/validationregulatory-acceptance/topical-toxicity/skin-corrosion; Available at: 14.07.2014.

49. The Critical Review of Methodologies and Approaches to Assess the Inherent Skin Sensitization Potential (skin allergies) of Chemicals, No 200961 04, http://ec.europa.eu/health/ scientific committees/docs/service_contract_20096104 en.pdf; Available at: 14.07.2014.

50. Pierard GE. Instrumental non-invasive assessments of cosmetic efficacy. J Cosmet Dermatol 2002; 2: 57-8.

51. Tupker RA, Pinnagoda J, Coenraads PJ, Nater JP. The influence of repeated exposure to surfactants on the human skin as determined by transepidemal water loss and visual scoring. Contact Dermatitis 1989; 20: 108-14

52. Parente ME, Gambaro A, Solana G. Study of sensory properties of emollients used in cosmetics and their correlation with physicochemical properties. J Cosmet Sci 2005; 56: 175-82.

53. Goldember RL, De la Rosa C. Correlation of skin feel of emollients to their chemical structure. J Soc Cosmet Chem 1999; 22: 635-54.

54. Kamershwarl V, Mistery N. Propriedadesensoriais Dos emolienres. Cosmet Toiletr 2001; 13L: 52057.

55. Feliczk-Guzik A, Bazarnik K, Nowak I. Analiza sensoryczna i ocean organoleptyczna substancji zapachowych w kosmetykach. Dermatol Estet 2014; 1: 23-7.

56. Noszczyk M. Kosmetologia pielęgnacyjna i lekarska. PZWL, Warsaw 2013

57. http://kosmetyka.farmacom.com.pl/pdf/PrezentacjalaboratoriumHamilton.pdf; Available at: 15.07.2014.

58. Deklaracja Helsińska Światowego Stowarzyszenia Lekarzy (WMA). Etyczne zasady prowadzenia badań medycznych z udziałem ludzi przyjęta przez 18 Zgromadzenie Ogólne 
Światowego Stowarzyszenia Lekarzy (WMA), Helsinki, Finlandia, czerwiec 1964 r. i zmieniona przez: 29, 35, 48, 52, 53, 55 i 59 Zgromadzenie Ogólne WMA z lat odpowiednio 1975, 1983, 1996, 2000, 2002, 2008 i 2013 r.

59. Dyrektywa 2001/20/WE Parlamentu Europejskiego i Rady z dnia 4 kwietnia 2001 r. http://ec.europa.eu/health/files/ eudralex/vol-1/dir_2001_20/dir_2001_20_pl.pdf; Available at: 14.07.2014.

60. Rozporządzenie Ministra Zdrowia z dnia 2 maja 2012 r. w sprawie Dobrej Praktyki Klinicznej (Dz. U. z 2012 r. Nr 0, poz. 489 ) http://isap.sejm.gov.pl/DetailsServlet?id=W DU20120000489; Available at: 14.07.2014.

61. Rozporządzenie Ministra Zdrowia z dnia 22 maja 2013 r. w sprawie Dobrej Praktyki Laboratoryjnej i wykonywania badań zgodnie z zasadami Dobrej Praktyki Laboratoryjnej (Dz.U. z 2013 poz. 665) p http://isap.sejm.gov.pl/Download ?id=WDU20130000665\&type=2. Available at: 14.07.2014. 